\title{
PERSEPSI MASYARAKAT UNTUK MEMILIH DAN TIDAK MEMILIH BANK SYARIAH (STUDI KOTA PALOPO)
}

\author{
Junaidi \\ STIE Muhammadiyah Palopo \\ Email : Junaidij45@Yahoo.co.id
}

\begin{abstract}
ABSTRAK
Indonesia merupakan negara dengan mayoritas penduduknya muslim. Namun hal ini tidak membuat bank-bank syariah menjadi bank yang besar karena minat dan pengetahuan masyarakat yang masih kurang. Hal ini disebabkan perkembangan sektor perbankan tidak terlepas dari perilaku nasabah dalam menentukan pilihannya, apakah akan menggunakan jasa perbankan syariah atau jasa perbankan konvensional. Oleh karena itu, perlu dilakukan penelitian untuk mengetahui seberapa besar faktor yang dapat mempengaruhi masyarakat di Kota Palopo untuk memilih bank syariah. Faktor-faktor tersebut antara lain religiusitas, pengetahuan, tingkat bagi hasil, fasilitas dan layanan dan lokasi bank syariah.Penelitian ini bertujuan menganalisis persepsi masyarakat dan nasabah terhadap bank syariah di Kota Palopo. Teknik pengumpulan data didapat melalui kuesioner. Hasil analisis deskripsi yang dilakukan, dapat diambil kesimpulan bahwa faktor penentu masyarakat muslim untuk memilih bank syariah adalah religiusitas dan pemahaman. Sedangkan pelayanan dan fasilitas tidak mempengaruhi keputusan masyarakat dalam arti bahwa aspek ini kurang mendukung responden untuk menjadinasabah atau memilih bank syariah.
\end{abstract}

Kata Kunci: Religiusitas, Pemahaman, Bagi Hasildan Lokasi.

\section{Latar Belakang}

Dengan terus berkembangnya industri perbankan syariah ini menyebabkan timbulnyapersaingan antar lembaga keuangan yaitu lembaga keuangan yang berbasis syariah dengan lembaga keuangan konvensional. Hal ini terjadi setelahdiberlakukannya UU perbankan tahun 1998 yang secara eksplisit mengetahuikeberadaan perbankan syariah sebagai salah satu lembaga intermediasi dalamproses pembangunan Indonesia, dengan tumbuh pesatnya institusi/lembagaperbankan syariah, diantaranya Bank Muamalat, Bank Mandiri Syariah, BNISyariah, BPD Syariah, BRI Syariah dll.

Indonesia merupakan suatu negara dengan sebagian besar penduduknyamuslim. Namun hal ini belum cukup membuat bank-bank syariah menjadi bankyang besar di Indonesia karena minat masyarakatnya yang masih kurang. Banksyariah seolah seperti sulit menembus dominasi perbankan konvensional, padahalmayoritas masyarakat Indonesia adalah muslim. Hal ini disebabkanperkembangan sektor perbankan tidak terlepas dari perilaku konsumen dalammenentukan pilihannya dalam menggunakan jasa perbankan, apakah akanmengguanakan jasa perbankan syariah atau jasa perbankan konvensional yangtelah dulu memainkan perannya di Industri perbankan Indonesia.

Hadirnya bank syariah di Indonesia masih terhitung baru. Keadaan yangdemikian membuat masyarakat ingin mengetahui lebih lanjut tentang banksyariah. Perkembangan perbankan syariah di Indonesia telah menjadi tolak ukurkeberhasilan eksistensi ekonomi syariah. Terbukti krisis 1998 telahmenenggelamkan bank-bank konvensional dan banyak yang dilikuidasi karenakegagalan sistem bunganya. Berbanding terbalik dengan bank syariah yang justrumampu bertahan dari badai krisis tersebut dan menunjukkan kinerja 
yangmeningkat. Hal ini dapat diamati dari perkembangan sistem keuangan syariahdalam kurun waktu sepuluh tahun terakhir ini yang secara bertahap terusmeningkat. (Seputro, 2013).

Upaya pengembangan perbankan syariah di Indonesia didukung secara intensif oleh tiga lembaga yaitu BI, Dewan Syariah Nasional-Majelis Ulama Indonesia (DSN-MUI) dan Komite Akuntansi Syariah-Ikatan Akuntan Indonesia (KAS-IAI). Berdasarkan Data statistik perbankan syariah BI, per Desember 2014jumlah perbankan syariah di Indonesia ada 11 buah dengan total aset perbankan syariah di atas Rp. 250 triliun. Dibandingkan periode satu tahun sebelumnya, aset perbankan syariah telah mengalamilebih dari $25 \%$.

Kendala terbesar perbankan syariah di Kota Palopo adalah terbatasnya sumber daya manusia(SDM) baik yang mempunyai dasar perbankan Syariah maupun yang mengelola perbankan syariah itu sendiri. Berdasarkan hasil konfirmasi kami ke beberapa perbankan Syariah di Kota Palopokebutuhan SDM di perbankan syariah dipenuhi dari SDM perbankan konvensional. Karenanya BI sejak tiga tahun terakhir menyelenggarakan sertifikasi manajer perbankan syariah. Itu dilakukan agar maindset perbankan syariah benar-benar tertanam dan dipraktekkan secara baik oleh manajer tersebut. (Sukiadi, 2013).

Pertumbuhan perbankan syariah ini tidak lepas dari kepercayaan pasar yang membaik. Bank Indonesia akan mengimplementasikan kebijakan strategis untuk mendorong syariah agar terus maju menjadi sebuah kebanggaan. Dalam perkembangan bank syariah mengalami berbagai kendala. Menurut Alamsyah (Priantina, 2012), ada tantangan jangka pendek dan jangka panjang yang harus diselesaikan agar perkembangan perbankan dan keuangan syariah dapat mencapai target dan terus mengalami percepatan.

Tantangan dalam jangka pendek yang harus segera diselesaikan adalah : Penyediaan Sumber Daya Insani (SDI), secara kuantitas maupun kualitas, inovasi pengembangan produk dan layanan perbankan syariah yang kompetitif dan berbasis kekhususan kebutuhan masyarakat, kontinuitas program sosialisasi dan edukasi kepada masyarakat. Sementara, tantangan yang harus diselesaikan dalam jangka panjang adalah: Perlunya kerangka hukum yang mampu menyelesaikan permasalahan keuangan syariah secara komprehensif. Salah satu masalah yang sampai sekarang belum selesai misalnya adalah tentang pajak ganda pada transaksi murabahah, perlunya kodifikasi produk dan standar regulasi yang bersifat nasional dan global untuk menjembatani perbedaan dalam fiqh muamalah .

Sejauh ini memang sering terjadi perbedaan pendapat diantara paraahli hukum Islam diantaranya mengenai aplikasi hukum muamalah yang dibolehkan maupun yang tidak, dan perlunya referensi nilai imbal hasil (rate ofreturn) bagi keuangan syariah. Keuangan syariah selalu didorong untuk menggunakan prinsip bagi hasil dalam kerangka partnership, sementara masingmasing jenis dan bidang usaha bisa jadi memberikan nilai imbal hasil dengan persentase yang berbeda beda. (Priantina, 2012).

Banyak tantangan dan permasalahan yang dihadapi dalam perkembanganBank Syariah, terutama berkaitan dengan penerapan suatu sistem perbankan yang baru yang mempunyai sejumlah perbedaan prinsip dari sistem keuntungan yang dominan dan telah berkembang pesat di Indonesia. Permasalahan ini dapat berupa permasalahan yang bersifat operasional perbankan maupun aspek dari lingkungan makro.

Beberapa kendala yang dihadapi dalam pengembangan Bank Syari ah antaralain (Sukiadi, 2013):

1. Permodalan. Kesulitan dalam pemenuhan permodalan ini antara lain disebabkan karena belum adanya keyakinan yang kuat pada pihak pemilik dana akan prospek dan masa depan keberhasilan Bank Syari ah, sehingga ditakutkan dana yang ditempatkan akan hilang, masih kuatnya perhitungan bisnis keduniawian pada pemilik dana sehingga ada rasa keberatan jika harus menempatkan sebagian dananya pada Bank Syari ah.

2. Peraturan Perbankanyang berlaku belumsepenuhnya mengakomodir operasional Bank Syari ah mengingat adanya sejumlah perbedaan dalam pelaksanaan operasional Bank 
Syari ah dengan Bank Konvensional. Ketentuan-ketentuan tersebut antara lain adalah hal-hal yang mengatur mengenai instrumen yang diperlukan untuk mengatasi masalah likuiditas, instrument moneter yang sesuai dengan prinsip syari ah untuk keperluanpelaksanaan tugas Bank Sentral, standar akuntansi, audit dan pelaporan, ketentuan-ketentuan yang mengatur mengenai prinsip kehati-hatian, dll.

3. Sumber Daya Manusiadisesabkan karena sistem perbankan syari ah masih belum lama dikenal di Indonesia. Disamping itu lembaga akademik danpelatihan ini masih terbatas, sehingga tenaga terdidik dan berpengalaman dibidang perbankan syari ah baik dari sisi bank pelaksana maupun bank sentral (pengawas dan peneliti bank). SDM dalam perbankan syari ah memerlukan persyaratan pengetahuan yang luas dibidang perbankan, memahami implementasi prinsip-prinsip syariah dalam praktek perbankan serta mempunyai komitmen kuat untuk menerapkannya secara konsisten.

4. Pemahaman Ummat. Pemahaman sebagian besar masyarakat mengenaisistem dan prinsip Perbankan Syariah belum tepat, bahkan diantara ulamadan cendekiawan muslim sendiri masih belum ada kata sepakat yang mendukung keberadaan Bank Syari ah, terbukti dari hasil pretest terhadap37 Dosen Fakultas Syariah dalam acara Orientasi Perbankan yang telah dilakukan oleh Asbisindo Wilayah Jatim beberapa waktu yang lalu memberikan jawaban yang tidak konsekwen dan cenderung ragu-ragu. Dan masih adanya masyarakat yang mengaku paham akan Syariah Islam, tetapi tidak mau menjalankannya seperti yang dialami oleh PT. BPR Syariah Baktimakmur Indah Sidoarjo dalam memberikan pembiayaan mudharabah dengan salah satu mitranya yang dikenal sebagai ulama yangmana sang ulama mau berbagi kerugian namun setelah untung tidak bersedia membagi keuntungannya dengan pihak Bank, yang tentunya bertentangan dengan akad yang telah disepakati di awal. Atau seorang ulama yang datang ke Bank dan menanyakan besarnya bunga atas simpanannya.

Peneliti tertarik untuk melakukan penelitian yang sama, namun berbeda objek dan waktunya. Peneliti ingin meneliti masyarakat Kota Palopo baik yang sudah bekerja maupun yang masih berstatus mahasiswa. Masyarakat Kota Palopo dianggap sudah bisa menentukan produk perbankan apa yang akan di pilih. Penelitian ini untuk mengetahui bagaimana persepsi masyarakat terhadap bank syariah diKota Palopo ?.

Tujuan penulis mengadakan penelitian ini adalah: Untuk mengetahuibagaimana masyarakat terhadap bank syariah di Kota Palopo.Manfaat dari penelitian ini adalahsebagai sumber informasi dan pengalaman untukmengetahui minat masyarakat terhadap pilihan sebuah bank, memberikan informasi serta masukan yangkaitannya penyebab masyarakat berminat terhadap perbankan, sertadapat memperbaiki kinerja perbankan ke depan menuju lebihprofessional. Adapun penelitian ini dilaksanakan pada semester pertama tahun 2015.

\section{Landasan Teori \\ Arti dan Fungsi Perbankan}

Kata bank dari kata banque dalam bahasa Prancis, dan dari banco dalambahasa Italia, yang berarti peti/lemari atau bangku. Kata peti atau lemari menyiratkan fungsi sebagai tempat menyimpan benda-benda berharga, seperti peti emas, uang dan sebagainya. Dalam Al-Quran istilah bank tidakdisebutkan secara eksplisit. Tetapi jika yang dimaksud adalah sesuatu yang memiliki unsur-unsur seperti sturuktur, manajemen, fungsi, hak dan kewajiban maka semua itudisebutkan dengan jelas, seperti zakat, sadaqah, ghanimah(rampasan perang), bai (jual beli), dyan (utang dagang), maal (harta), dan sebagainya, yang memiliki fungsi yang dilaksanakan oleh peran tertentu dalam kegiatan ekonomi (Sudarsono: 2008). 
Menurut Undang-undang Nomor 10 Tahun 1998 tentang Perubahan atasUndangundang No. 7 tahun 1992 tentang Perbankan , lembaga keuangan bank terdiri atas bank umum dan Bank Perkreditan Rakyat. Bank umum dan bank perkreditan rakyat dapatr memilih untuk melaksankan kegiatan usahanya atas dasar prinsip bank konvensional atau bank berdasarkan prinsip syariah. Abdurrachman dalam Ensiklopedia Ekonomi Keuangan dan perdagangan(1993) menjelaskan bahwa, bank adalah suatu jenis lembaga keuangan yang melaksanakan berbagai macam jasa, seperti memberikan pinjaman, mengedarkan mata uang, pengawasan terhadap mata uang, bertindak sebagai tempat penyimpanan benda-benda berharga, membiayai usaha perusahaan-perusahaan dan lain-lain.

Pada umumnya yang dimaksud dengan bank syariah adalah lembaga keuangan yang usaha pokoknya memberikan kredit dan jasa-jasa lain dalam lalu lintas pembayaran serta peredaran uang yang beroperasi disesuaikan dengan prinsip-prinsip syariah. Oleh karena itu, usaha bank akan selalu berkaitan dengan masalah uang sebagai dagangan utamanya. Kegiatan dan usaha bank akan selalu berkait dengan komoditas antara lain:

1. Pemindahan uang,

2. Menerima dan membayaran kembali uang dalam rekening koran,

3. Mendiskonto surat wesel, surat order maupun surta-surat berharga lainnya,

4. Membeli dan menjual surat-surat berharga,

5. Membeli dan menjual cek wesel, surta wesel, kertas dagang,

6. Memberi kredit, dan

7. Memberi jaminan kredit.

\section{Fungsi dan Peran Bank}

Secara umum, fungsi utama bank adalah menghimpun dana dari masyarakatdan menyalurkan kembali kepada masyarakat untuk berbagai tujuan atau sebagai financial intermediary. Secara lebih spesifik bank dapat berfungsi sebagai agentof trust, agent of development, dan agent of services. (Putra:2009):

a. Agent of Trust

Dasar utama kegiatan perbankan adalah kepercayaan (trust), baik dalamhal penghimpunan dana maupun penyaluran dana. Pihak masyarakat maupun bank sendiri akan menempatkan atau menyalurkan dananya pada debitor atau masyarakat apabila dilandasi adanya unsur kepercayaan. Pihak bank percaya bahwa debitor tidak akan menyalahgunakan pinjamannya, debitor akan mengelola dana pinjaman dengan baik, debitor akan mempunyai kemampuan untuk membayar pada saat jatuh tempo, dan debitor mempunyai niat baik untuk mengembalikan pinjaman beserta kewajiban lainnya pada saat jatuh tempo.

b. Agent of Development

Kegiatan perekonomian masyarakat di sektor moneter dan di sektor riiltidak dapat dipisahkan. Kedua sektor tersebut selalu berinteraksi dan saling mempengaruhi. Sektor riil tidak akan dapat berkinerja dengan baik apabila sektor moneter tidak bekerja dengan baik. Kegiatan bank berupa penghimpunan dan penyaluran dana sangat diperlakukan bagi lancarnya kegiatan perekonomian di sektor riil. Kegiatan bank tersebut memungkinkan masyarakat melakukan kegiatan investasi, kegiatan investasi-disribusikonsumsi tidak dapat dilepaskan dari adanya penggunaan uang.

c. Agent of Services

Disamping melakukan kegiatan penghimpunan dan penyalurkan dana,bank juga memberikan penawaran jasa perbankan yang lain kepada masyarakat. Jasa yang ditawarkan bank ini erat kaitannya dengan kegiatan perekonomian masyarakat secara umum. Jasa ini antara lain dapat berupa jasa pengiriman uang, penitipan barang berharga, pemberian jaminan bank, dan dan penyelesaian tagihan. 


\section{Konsep Perbankan Syariah}

Perbankan syariah adalah perbankan yang berlandaskan kepada Al-Qurandan Al-Hadits dalam menjalankan kegiatan usahanya. Sistem perbankan syariah mengharamkan transaksi yang mengandung riba, gharar, dan masyir. Dalam konteks perbankan nasional Indonesia, Islamic Banking diistilahkan dengan Bank umum atau Bank Perkreditan Rakyat yang pembiayaannya berdasarkan padaprinsip-prinsip Islam.

Prinsip Islam dalam konteks tersebut adalah aturan perjanjian berdasarkan hukum Islam antara bank pihak lain untuk menyimpan dana dan atau pembiayaan kegiatan usaha antara lain pembiayaan berdasarkan prinsip bagi hasil (mudharabah), pembiayaan berdasarkan prinsip penyertaan modal (musyarakah), prinsip jual beli barang dengan memperoleh keuntungan (murabahah), atau pembiayaan barang modal berdasarkan prinsip sewa murni tanpa pilihan (ijarah), atau dengan adanya pilihan pemindahan kepemilikan atas barang yang disewa dari pihak bank oleh pihak lain (ijarah wa iqtina).

\section{Landasan Operasional Perbankan Syariah}

Menurut karim (2005) dan Antonio (2010) landasan operasional perbankan syariah :

a. Tidak membenarkan transaksi spekulatif, jual beli atas suatu barang yangdibeli (gharar) dan jual beli yang mengandung unsur riba.

b. Dalam berinteraksi dengan nasabah, bank syariah memosisikan diri sebagaimitra investor dan pedagang, bukan dalam hubungan lender dan borrowersebagaimana yang berlaku pada bank konvensional.

c. Akad transaksi yang sudah disepakati dengan nasabah tidak akanmengalami perubahan sampai dengan berakhirnya walaupun terjadi gejolak moneter.

\section{Prinsip dasar sistem Keuangan Islam}

Secara umum dalamsistem keuangan Islam berkisar pada konsep dan prinsip tawhid, khalifatullahi fil ard dan al-adl serta semua transaksi sesuai tuntunan Al-Qur an dan Sunnah Nabi Muhammad SAW diantaranya larangan atas penghasilan apapun yang mengandung Riba dan legalitas laba serta adanya prinsip tolong menolong bukan hanya ditujukan untuk sesama umat muslim melainkan seluruh umat manusia di dunia. Riba yang secara umum dikenal sebagai bunga adalah tambahan yang diambil sebagai premi (nilai tambah) dari debitur yang mewakili tingkat pengembalian atas transaksi yang melibatkan pertukaran uang dengan uang atau sebagai tambahan karena adanya keterlambatan dalam pembayaran atas harga yang telah disepakati dari jual beli atau utang piutang (Chapra, 1995,2006 ; Khan, 2010; Shiddiqi, 2004; Sulaiman, 2006).

Tujuan keseluruhan penerapan prinsip syariah menurut Ayub (2007) adalah untuk menciptakan kebahagiaan dan kesejahteraan umat manusia dan mengurangi kesenjangan kepemilikan kekayaan serta adanya kesatuan antara aktivitas ekonomi dan agama. Konsep kebahagiaan dari perspektif Islam berbeda dengan konsep kesenangan menurut ekonomi positif (konvensional). Oleh karena itu, semua hal yang menjamin kesejahteraan dan memenuhi kepentingan utama dari umat manusia harus sesuai dengan filosofi Islam.

Menurut El-Hawary et.al (2004) dalam sistem keuangan Islam, riba transaksi yang mengakibatkan kerugian salah satu pihak dan adanya unsur ketidakpastian diharamkan karena menimbulkan kekacauan dan ketidakseimbangan dilarang keras seperti krisis ekonomi dan keuangan yang pernah dialami Amerika, Indonesia dan negara lainnya serta apa yang dialami sebagian neraga Eropa dan selama sistem riba diterapkan kejadian tersebut akan terus berulang dan terus terjadi apalagi dinegara berkembang dan miskin.

Selain penolakan atas Riba (bunga), menurut El-Hawaray et.al (2004) sistem keuangan Islam juga tidak memperbolehkan adanya transaksi yang mengandung risiko yang berlebihan atau permainan peluang apapun yang dapat menuntun pada eksploitasi dan 
kerugian bagi salah satu atau kedua belah pihak yang dalam istilah ekonomi sering disebut zero sum game. Walaupun dalam prakteknya banyak kritik yang ditujukan kepada lembaga keuangan Islam karena prakteknya menyimpang dari filosofi lembaga keuangan syariah didirikan dan tidak jauh berbeda dengan sistem konvensional karena ada indikasi memberatkan salah satu pihak (Chong dan Liu, 2009; Dar dan Presley, 2000; Khan, 2010).

Berdasarkan penjelasan diatas dapat disimpulkan bahwa tujuan dari pelaksanaan prinsip-prinsip syariah dalam sistem keuangan yang berbasis syariah adalah berupa tuntunan bagaimana manusia berhubungan dengan sesama makhluk di dunia dan bagaimana manusia berhubungan dengan sang pencipta (Allah SWT). Tujuan ini sering disebut sebagai tujuan primer yang merupakan perlindungan dan pemeliharaan atas agama, kehidupan, keturunan (anggota keluarga), harta, intelek dan kehormatan. Sedangkan tujuan sekunder dari pelaksanaan prinsip-prinsip syariah adalah :

1. Penegakan keadilan dan kesamaan dalam masyarakat

2. Peningkatan keamanan sosial, sikap saling membantu dan solidaritas khususnya untuk membantu yang miskin serta membutuhkan dalam memenuhi kebutuhan dasar mereka.

3. Pemeliharaan kedamaian dan keamanan

4. Peningkatan kerja sama dalam hal kebaikan

5. Peningkatan nilai moral universal yang utama dan semua tindakan yang perlu untuk pemeliharaan dan penguasaan alam.

\section{Karakteristik yang Mempengaruhi Perilaku Kosumen}

Teori awal mengenai mengenai perilaku konsumen didasarkan pada teoriekonomi, dengan pendapat bahwa individu bertindak secara rasional untuk memaksimumkan keuntungan mereka dengan membeli barang atau jasa. Namun penelitian belakangan menemukan para konsumen mungkin sekali membeli secara impusif dan dipengaruhi oleh keluarga dan teman-teman, oleh berbagai pemasang iklan dan model peran, tetapi juga oleh suasana hati, keadaan, dan emosi (Schiffman\&Kanuk 2008).

Menurut Kotler dan Amstrong (2001), pembelian konsumen dalam arti luas; barang dan jasa secara kuat dipengaruhi oleh karakter budaya, sosial, dan psikologis. Pada umumnya, orang pemasaran tidak dapat mengendalikan faktor-faktor semacam itu, tetapi mereka harus memperhitungkannya.

\section{Faktor-Faktor yang Mempengaruhi Konsumen}

Faktor-faktor yang mempengaruhi keputusan konsumen (Mowen danMichael: 2002):,

\section{a. Faktor Budaya}

Budaya adalah faktor mendasar dalam pembentukan norma-norma yangdimiliki seseorang yang kemudian membentuk atau mendorong keinginandan perilakunya menjadi seseorang konsumen. Budaya meliputi hal-hal yang dipelajari dari keluarga, tetangga, teman, guru, dan tokoh-tokohmasyarakat yang meliputi:

1) Nilai-nilai adalah norma yang di anut masyarakat.

2) Persepsi adalah cara pandang sesuatu.

3) Preferensi adalah rasa lebih suka pada sesuatu dibandingkan denganyang lainya.

4) Behavior (tindak tanduk).

Faktor-faktor budaya memberikan pengaruh paling luas pada keinginandan perilaku konsumen. Divisi pemasaran termasuk public relation pada perguruan tinggi contohnya perlu memahami peranan dari budaya, subbudaya; meliputi kewarganegaraan, agama, kelompok ras, dan daerah geografis. Banyak sub kebudayaan yang membentuk segmen pasar penting, 
dan orang pemasaran seringkali merancang produk dan program pemasaran yang disesuaikan dengan kebutuhan mereka.

Dalam pemilihan perguruan tinggi misalnya, konsumenmuslim memiliki pertimbangan berdasar nilai-nilai yang berasal dari agama yang diyakininya (nilai keislaman). Dengan demikian, pihak pemasar dari institusi tersebut harus memiliki perbedaan pendekatan dalam melayani segmen pasar yang berbeda.

\section{b. Faktor Sosial}

Anggota keluarga dapat sangat mempengaruhi perilaku pembeli.

Keluargaadalahorganisasi pembelian kosumen paling penting dalam masyarakat, dan pengaruh tersebut telah diteliti secara ekstensif.

1) Faktor pembeli. Keputusan seorang pembeli juga dipengaruhi olehkarakteristik pribadi seperti umur pembeli dan tahap siklus hidup,pekerjaan, situasi ekonomi, gaya hidup, serta kepribadian dan konsep diri.

2) Reference group adalah kelompok yang mempengaruhi anggotanyadalam membuat keputusan pembelian sesuatu barang dan jasa meskipun ada pengecualian pada sebagian orang.

\section{c. Faktor teknologi}

1) Transportasi pribadi, mobil dan motor bertambah dari tahun ketahun berikut kecanggihan teknologinya yang bertambah dari tahun ke tahun.

2) Audio visual, telah menjadi produk pemikat perorangan sejakpuluhan tahun lalu, baik untuk dinikmati oleh diri sendiri maupun untuk keluarga.

3) Internet dan seluler kemajuan komputer pribadi, telepon selularmeningkatkan pasar hardware.

\section{d. Faktor-Faktor Psikologis}

Pilihan-pilihan seseorang dalam membeli dipengaruhi oleh empat faktorpsikologi yang penting: motivasi, persepsi, pengetahuan dan keyakinanserta sikap.

\section{Metode Penelitian}

Dalam penelitian ini mengunakan data primer yaitu jenis data yang diperoleh dan digali dari sumber utamanya (sumber asli), baik berupa data kualitatif maupun data kuantitatif (Teguh, 2001:122). Data dikumpulkan dengan cara wawancara dan kuesioner kepada 100 orang responden terpilih. Populasi pada penelitian ini adalah masyarakat Kota Palopo yang berpotensi menjadi nasabah bank syariah. Elemen-elemen dalam populasi dibagi kedalam cluster atau kelompok, jika ada beberapa kelompok dengan heterogenitas dalam kelompoknya dan homogenitas antar kelompok. Teknik cluster ini digunakan oleh penulis di lapangan yang wilayahnya luas. Dalam penelitian ini jumlah responden yang diambil sebagai sampel dan dianggap dapat mewakili seluruh populasi adalah sebanyak 100 responden. Responden tersebut antara lain mahasiswa, pekerja sektor formal dan sektor informal di Kota Palopo yang menggunakan fasilitas jasa perbankan.

\section{Variabel Penelitian}

1. Tingkat Religiusitas Masyarakat

Religius adalah keadaan dimana dalam diri seseorang dalam merasakan dan mengakui adanya kekuatan tertinggi yang menaungi kehidupan manusia dengan cara melaksanakan 
semua perintah Tuhan dan meninggalkan seluruh larangannya, sehingga hal ini akan membawa ketenangan dan ketentraman diri. Indikator :
a. Keberpihakan kepada umat,
b. Sesuai syariat islam,
c. Mekanisme perbankan dijalankan sesuai dengan syariah,
d. Bank syariah tidak menggunakan prinsip bunga.

2. Tingkat Bagi Hasil Tabungan Bank Syariah

Tabungan bank syariah ini berlandaskan bagi hasil berorientasi kemaslahatan hidup umat manusia (Antonio, 1999). Seperti halnya dalam transaksi bank syariah untung dan rugi di tanggung bersama. Indikator :
a. Tingkat bagi hasil yang adil
b. Tingkat bagi hasil menguntungkan bagi pihak bank dan nasabah
c. Tingkat bagi hasil yang rendah
d. Tingkat Jaminan yang tinggi
e. Tingkat Denda yang rendah.

3. Pelayanan dan Fasilitas

Fasilitas adalah sesuatu yang dapat membantu memudahkan pekerjaan, tugas dan sebagainya. Fasilitas yang diberikan oleh bank syariah dapat menjunjung kinerja staf dan menarik minat masyarakat untuk memilih bank syariah. Indikator :
a. Profesional staf karyawan,
b. Karyawan yang ramah,
c. Suasana bank yang nyaman,
d. Penampilan dan pakaian staf yang sopan,
e. Mudah menjadi nasabah di bank syariah,
f. Bank syariah menawarkan produk yang variatif.

4. Lokasi

Letak geografis yang menyediakan berbagai fasilitas untuk tujuan tertentu. Seperti halnya pendirian bank syariah, adanya bank syariah ini untuk transaksi jasa keuangan di zaman yang semakin maju. Indikator :
a. Lokasi bank yang terjangkau,
b. Banyak cabang,
c. Kantor cabang utama yang nyaman.

\section{Metode Pengumpulan Data}

Metode pengumpulan data dimaksudkan untuk memperoleh informasi yang relevan, akurat dan reliabel. Dalam penelitian ini dilakukan dengan metode angket (kuesioner atau daftar pertanyaan) merupakan teknik pengumpulan data yang dilakukan dengan cara memberi seperangkat pertanyaan atau pernyataan tertulis kepada responden untuk di jawab oleh responden (sugiyono, 2004). Untuk mendapatkan informasi berbagai hal yang menunjang penelitian didukung dengan wawancara secara langsung.

\section{Hasil Analisis dan pembahasan \\ Analisis Deskripsi Variabel}

a. Analisis Deskripsi Variabel Religiusitas 
Tabel 4.11

Penilaian Responden terhadap Religiusitas

\begin{tabular}{|l|c|c|c|}
\hline \multicolumn{1}{|c|}{ Variabel } & Mean & STD & Kategori \\
\hline Bank syariah berpihak kepada umat & 5,75 & 1,048 & Sangat Setuju \\
\hline Bank syariah sesuai syariat Islam & 5,71 & 0,935 & Setuju \\
\hline Mekanisme bank syariah sesuai syariah & 5,08 & 1,220 & Setuju \\
\hline $\begin{array}{l}\text { Bank syariah tidak menggunakan } \\
\text { prinsip bunga }\end{array}$ & 5,27 & 1,053 & Sangat Setuju \\
\hline $\begin{array}{l}\text { Penyaluran dana untuk kegiatan } \\
\text { yang halal dan menguntungkan }\end{array}$ & 6,49 & 0,904 & $\begin{array}{c}\text { Sangat Setuju } \\
\text { Sekali }\end{array}$ \\
\hline \multicolumn{1}{|c|}{ Religiusitas } & 5,75 & 0,669 & Setuju \\
\hline
\end{tabular}

Sumber : Data Primer Diolah, 2016.

Berdasarkan Tabel 4.11 di atas dari 100 responden yang diambil sebagaisampel, menganggap kebanyakan responden menilai indikator variabel religiusitas sangat menarik (Mean 5,75). Hal ini menunjukkan bahwa Bank Syariah berpihak kepada umat, Bank Syariah sesuai syariat Islam, Mekanisme Bank Syariah sesuai syariah, Bank Syariah tidak menggunakan prinsip bunga, dan Penyaluran dana untuk kegiatan yang halal dan menguntungkan.

b. Analisis Deskripsi Variabel Tingkat Bagi Hasil Tabungan Bank Syariah

Tabel 4.12

Penilaian Responden terhadap Tingkat Bagi Hasil Tabungan Bank Syariah

\begin{tabular}{|l|c|c|c|}
\hline \multicolumn{1}{|c|}{ Variabel } & Mean & STD & Kategori \\
\hline Tingkat bagi hasil yang adil & 5,51 & 1,168 & Sangat Setuju \\
\hline $\begin{array}{l}\text { Tingkat bagi hasil menguntungkan bagi pihak bank } \\
\text { dan nasabah }\end{array}$ & 5,78 & 1,244 & Sangat Setuju \\
\hline $\begin{array}{l}\text { Tingkat bagi hasil bank syariah } \\
\text { lebih tinggi dari tingkat bunga bank konvensional }\end{array}$ & 5,63 & 1,315 & Sangat Setuju \\
\hline Tingkat Bagi Hasil Tabungan Bank Syariah & $\mathbf{5 , 6 4}$ & 0,987 & Sangat Setuju \\
\hline
\end{tabular}

Sumber : Data Primer Diolah, 2016.

Berdasarkan Tabel 4.12 di atas dari 100 responden yang diambil sebagai sampel, diketahui kebanyakan responden menilai indikator variabel Tingkat Bagi Hasil Tabungan Bank Syariah, sangat menarik (Mean 5,64). Hal ini menunjukkan bahwa tingkat bagi hasil yang adil, tingkat bagi hasil menguntungkan bagi pihak bank dan nasabah, dan tingkat bagi hasil Bank Syariah lebih tinggi dari tingkat bunga bank konvensional.

d. Analisis Deskripsi Variabel Pelayanan dan Fasilitas Bank Syariah

Tabel 4.13

Penilaian Responden terhadap Pelayanan dan Fasilitas Bank Syariah

\begin{tabular}{|l|c|c|c|}
\hline \multicolumn{1}{|c|}{ Variabel } & Mean & STD & Kategori \\
\hline Tingkat bagi hasil yang adil & 4,56 & 1,373 & Setuju \\
\hline $\begin{array}{l}\text { Tingkat bagi hasil yang menguntungkan bagi } \\
\text { pihak bank dan nasabah }\end{array}$ & 4,92 & 1,261 & Setuju \\
\hline
\end{tabular}




\begin{tabular}{|l|c|c|c|}
\hline $\begin{array}{l}\text { Tingkat bagi hasil Bank Syariah lebih rendah } \\
\text { dari tingkat bunga bank konvensional }\end{array}$ & 5,12 & 1,297 & Setuju \\
\hline Tingkat jaminan yang tinggi & 5,20 & 1,198 & Setuju \\
\hline Tingkat denda yang rendah & 6,00 & 1,287 & Sangat Setuju \\
\hline $\begin{array}{l}\text { Tingkat Bagi Hasil Pinjaman } \\
\text { Bank Syariah }\end{array}$ & $\mathbf{5 , 1 6}$ & $\mathbf{0 , 9 6 8}$ & Setuju \\
\hline
\end{tabular}

Sumber : Data Primer Diolah, 2016.

Berdasarkan Tabel 4.13 di atas dari 100 responden yang diambil sebagai sampel, diketahui kebanyakan responden menilai indikator Tingkat Bagi Hasil Pinjaman Bank Syariah, Setuju (Mean 5,16). Hal ini menunjukkan bahwa tingkat bagi hasil yang adil, tingkat bagi hasil yang menguntungkan bagi pihak bank dan nasabah, tingkat bagi hasil Bank Syariah lebih rendah dari tingkat bunga bank konvensional, tingkat jaminan yang tinggi, dan tingkat denda yang rendah.

d. Analisis Deskripsi Variabel Pelayanan dan Fasilitas Bank Syariah

Tabel 4.14

Penilaian Responden terhadap Pelayanan dan Fasilitas Bank Syariah

\begin{tabular}{|l|c|c|c|}
\hline \multicolumn{1}{|c|}{ Variabel } & Mean & STD & Kategori \\
\hline Staf dan karyawan profesional & 3,98 & 0,791 & Setuju \\
\hline Suasana bank yang nyaman & 3,90 & 0,674 & Sangat Setuju \\
\hline Menawarkan produk yang variatif & 4,20 & 0,964 & Setuju \\
\hline Ketersediaan ATM dibeberapa lokasi & 4,43 & 0,924 & Sangat Setuju \\
\hline Transaksi cepat dan tepat & 4,16 & 0,825 & Sangat Setuju \\
\hline $\begin{array}{l}\text { Pelayanan dan Fasilitas Bank } \\
\text { Syariah }\end{array}$ & 4,19 & 0,985 & Sangat Setuju \\
\hline
\end{tabular}

Sumber : Data Primer Diolah, 2014.

Berdasarkan Tabel 4.14 di atas dari 100 responden yang diambil sebagai sampel, diketahui kebanyakan responden menilai indikator Pelayanan dan Produk Bank Syariah, Setuju (Mean 4,12). Hal ini menunjukkan bahwa staf dan karyawan cukup professional, suasana bank yang cukup nyaman, ketersediaan ATM di beberapa lokasitransaksi cukup cepat dan tepat, adanya layanan E-Banking, dan tempat parkir yang cukup luas.

\section{Pembahasan}

Hasil analisis deskripsi diketahui kebanyakan responden menilai indikatorvariabel Religiusitas sangat menarik (Mean 5,75). Hal ini menunjukkan bahwa Bank Syariah berpihak kepada umat, Bank Syariah sesuai syariat Islam, Mekanisme Bank Syariah sesuai syariah, Bank Syariah tidak menggunakan prinsip bunga, dan Penyaluran dana untuk kegiatan yang halal dan menguntungkan.

Religius adalah keadaan dimana dalam diri seseorang dalam merasakan dan mengakui adanya kekuatan tertinggi yang menaungi kehidupan manusia dengan cara melaksanakan semua perintah Tuhan dan meninggalkan seluruh larangannya, sehingga hal ini akan membawa ketenangan dan ketentraman diri. Religius merupakan salah satu faktor yang tidak mempengaruhi masyarakat muslim untuk tidak memilih bank syariah. Menurut analisis data yang tidak signifikan sehingga tidak mempengaruhi masyarakat muslim untuk tidak memilih bank syariah dan secara negatif berarti semakin tinggi tingkat relijiusitas masyarakat muslim maka akan cenderung untuk memilih bank syariah, begitu pula sebaliknya. 
Hasil analisis deskripsi kebanyakan responden menilai indikator variabel Tingkat Bagi Hasil Tabungan Bank Syariah sangat menarik (Mean 5,64). Hal ini menunjukkan bahwa tingkat bagi hasil yang adil, tingkat bagi hasil menguntungkan bagi pihak bank dan nasabah, dan tingkat bagi hasil Bank Syariah lebih tinggi dari tingkat bunga bank konvensional. Dalam penelitian Hafeez (2008) tentang An Empirical Analysis Of the Determinants Of Bank Selection inPakistan A Customer View menyebutkan bahwa faktor penting bagi nasabah dalam memilih bank adalah Tingkat Bagi Hasil Tabungan bank.

Hasil analisis deskripsi diketahui kebanyakan responden menilai indikator Pelayanan dan Fasilitas Bank Syariah, Setuju (Mean 4,11). Hal ini menunjukkan bahwa staf dan karyawan cukup professional, menawarkan produk yang cukup variatif, ketersediaan ATM di beberapa lokasi, transaksi cukup cepat dan tepat dan tempat parkir yang cukup luas. Hal ini dapat diperkuat dari buku lembaga dan keuangan syariah menyebutkan bahwa sumber daya manusia tidak diimbangi dengan latar belakang disiplin keilmuwan di bidang perbankan syariah dan kurangnya akademisi perbankan syariah (Sudarsono:2008).

Menurut M. LuthfiHamidi dalam jurnal Pengembangan Bisnis dan Manajemen (2008) menyebutkan mutu pelayanan manajemen keuangan bank syariah yang masih belum baik. Hal inilah yang menjadi pertimbangan mahasiswa untuk tidak menggunakan bank syariah. Fasilitas dan layanan merupakan salah satu faktor yang mempengaruhimasyarakat untuk memilih bank syariah. Signifikan secara negatif dari hasil olah data dengan menggunakan metode logit menunjukkan bahwa variable fasilitas dan layanan yang diberikan oleh bank syariah menunjukkan dapat mempengaruhi keputusan untuk memilih bank syariah.

Berdasarkan analisis deskripsi ini dapat disimpulkan bahwa walaupun rata-rata responden menganggap positif bank syariah pada aspek religiusitas, tingkat bagi hasil tabungan bank syariahakan tetapi rata-rata responden juga menganggap kurang positif terhadap aspek pelayanan dan Fasilitas Bank Syariah dan lokasi Bank Syariah, sehingga hal ini yang memungkinkan responden tidak memilih bank syariah. Dengan kata lain bahwa faktor penentu masyarakat Islam untuk memilih Bank Syariah adalah pelayanan dan Fasilitas Bank Syariah dan lokasi Bank Syariah. Dalam arti bahwa aspek relijiusitas dan bagi hasil ini kurang mendukung responden untuk menjadi nasabah atau memilih bank syariah.

\section{SIMPULAN DAN SARAN}

Kesimpulan dan saran dari penelitian mengenai Persepsi masyarakat Terhadap Bank Syariah di Kota Palopo . Kesimpulan yang diperoleh dari hasil penelitian yang dilakukan dan saran akan diuraikan sebagai berikut :

\section{Kesimpulan}

1. Hasil analisis deskripsi diketahui kebanyakan responden nasabah bank konvensional menilai indikator variabel sudah Religiusitas dan sangat menarik (Mean 5,75) dengan interval skala 5,26 s/d 6,10.

2. Hasil analisis deskripsi diketahui kebanyakan responden menilai indikator variabel Tingkat Bagi Hasil Tabungan Bank Syariah sangat menarik (Mean 5,64) dengan interval skala $5,26 \mathrm{~s} / \mathrm{d}$ 6,10.

3. Hasil analisis deskripsi diketahui kebanyakan responden menilai Tingkat Bagi Hasil Pinjaman Bank Syariah menarik (Mean 5,16) dengan interval skala 4,41 s/d 5,25.

4. Hasil analisis deskripsi diketahui kebanyakan responden menilai indikator Pelayanan kurang memuaskan (Mean 4,11) dengan interval skala 3,56 s/d 4,40.

5. Hasil analisis deskripsi diketahui kebanyakan responden menilai indikator Lokasi Bank Syariah, kurang memuaskan (Mean 3,98). Dengan interval skala 3,56 s/d 4,40. 


\section{Saran}

Sehubungan dengan pelayanan dan lokasi adalah faktor penentu masyarakat Islam tidak Memilih Bank Syariah, maka dapat disarankan bagiBank Syariah Kota Palopo untuk lebih meningkatkan variabel tersebut dengan cara para karyawan lebih professional, karyawan lebih ramah danberpenampilan sopan, suasana bank yang lebih nyaman, menawarkan produk yang lebih variatif, ketersediaan ATM di beberapa lokasi, transaksi lebih cepat dan tepat, sehingga masyarakat Islam lebih banyak memilih Bank Syariah.

\section{DAFTAR PUSTAKA}

Abdurrahman, A. 1993, Ensiklopedia, Ekonomi, Keuangan, Perdagangan , PradyaParamita, Jakarta.

Antonio, Muhammad. 2001，Bank Syariah dari Teori ke Praktik , Gema Insani Press, Jakarta.

Capra, Umer M. 2000， Sistem Moneter Islam Edisi terjemahan, Gema InsaniPress dan Tazkia Cendekia. Jakarta.

Choir, 2010, Pertumbuhan Perbankan Syariah di Yogyakarta LampauiPerbankan Konvensional . Artikel. Zonaekis.com

Hafees and Ahmed. 2008, An Emirical Analysis of the Determinans of Bank Selection in Pakistan A Customer View, Pakistan Economic and Social Review, Volume 46,No.2,pp.147-160

Kotler dan Amstong. 2001, Prinsip-Prinsip Pemasaran Jilid 1, Erlangga, Jakarta.

Kotler, Philip. 1997, Manajemen Pemasaran , Indeks, Jakarta.

Misanam dan Liana.2007, Bunga Bank, Bagi Hasil, dan Relijiusitas: Suatu Investigasi Loyalitas Nasabah Terhadap Perbankan Syariah , JurnalSinergi Kajian Bisnis dan Manajemen Vol. 9, No.1, Hal. 69-86

Muflih, Muhammad M.A. 2006. Perilaku Konsumen dalam Perspektif IlmuEkonomi , Raja Grafindo Persada, Jakarta.

Mowen, C. J. dan Michael Minor. 2002， Perilaku Konsumen , Erlangga, Jakarta.

Nurgiyantoro Burhan, dkk. 2001, Statistik Terapan untuk Penelitian Ilmu-ilmuSosial , Gadjah Mada University Press, Jogjakarta.

Putra. 2009, Definisi, Fungsi dan Peranan Bank Umum dalam Perekonomian ,Diambil 23 Pebruari 2015

Priantina, Anita, 2012, Perjalanan Perbankan Syariah di Indonesia . Artikel. Detik.com.

Rais. 2008, Faktor-Faktor Yang Mempengaruhi Mahasiswa Untuk TidakMenggunakan

Bank Syariah: Studi di STIE Pengembangan Bisnis danManajemen , Jurnal

Pengembangan Bisnis dan Manajemen, Volume VIII, No. 12 
Schiffman dan Kanuk. 2004, Perilaku Konsumen Edisi 7, Indeks, Jakarta.

Seputro, Bijak. 2013. Perkembangan Perbankan Syariah di Indonesia . Artikel. Detik.com.

Subiyakto, Haryono dan Algifari, 2011, Praktikum Statistika Dengan MS Exceldan SPSS . STIE YKPN, Yogyakarta.

Sudarsono, Heri. 2008, Bank dan Llemabaga Keuangan Syariah : Edisi 3,Ekonisia, Yogyakarta.

Sugiyono. 2004. Metode Penelitian Bisnis . CV Alfabeta, Bandung.

Sukiadi, Tjuk K. 2013. Peluang dan Kendala Pengembangan Ekonomi Islam di Indonesia . Artikel Eonomi Syariah.

Suprapto, J. 2001, Statistik; Teori dan Aplikasi , Jilid 2, edisi keenam. Jakarta, Erlangga.

Suryanto, 2013. Persentase Jumlah Umat Islam Berbagai Daerah DiIndonesia . Artikel Info Islami. Begawanariyanta.wordpress.com.

Suslamanto, Dwi. 2013. Pertumbuhan Perbankan Syariah di Yogya Lampaui Perbankan Konvensional . Artikel Zona Ekonomi Islam.

Teguh, Muhammad. 2001, Metodologi Penelitian Ekonomi : Teori danAplikasi , PT Raja Grafindo Persada, Jakarta.

Wijaya, Alfi. 2009, Segmentasi dan Perilaku Konsumen pada Perbankan Syariah di Yogyakarta , Jurnal Ekonomi dan Bisnis Islam, Hal 143-165. 